\title{
Two New Species of Deep-Water Corallimorpharia (Cnidaria: Anthozoa) from the Northeast Pacific, Corallimorphus denhartogi and C. pilatus ${ }^{1}$
}

\author{
Dapbne G. Fautin, ${ }^{2}$ Tracy R. Wbite, ${ }^{2}$ and Katherine E. Pearson ${ }^{2,3}$
}

\begin{abstract}
Corallimorpharia is currently considered an order of hexacorallian anthozoans. Being skeletonless, its members are sometimes referred to as sea anemones, but they are morphologically more similar to members of Scleractinia than to members of Actiniaria. We describe two new species of corallimorpharians from deep water off the west coast of North America as Corallimorpbus denhartogi, n. sp. and Corallimorphus pilatus, n. sp. The former occurs at depths of 2550-4300 $\mathrm{m}$ from Oregon to Baja California, and the latter at depths of $198-900 \mathrm{~m}$ from British Columbia to southernmost California. The average size of individuals of $C$. denbartogi is greater than that of $C$. pilatus, and tentacles of the latter are more densely arrayed and relatively longer than those of the former. The distribution and sizes of their cnidae distinguish them from one another as well as from their four congeners, which are widely distributed in the world's oceans. In the collections we examined, specimens of $C$. denhartogi are more common than those of $C$. pilatus.
\end{abstract}

Corallimorpharia is CURRENTLY considered an order of hexacorallian anthozoans. Its members are skeletonless, and so are sometimes referred to as sea anemones, but are characterized by anatomy and nematocysts that more closely ally them with "true" or

1 This research was supported by NSF grants DEB9521819 and DEB9978106 in the PEET program to D.G.F. Some specimens of Corallimorpbus denbartogi were collected on cruises funded by National Science Foundation (NSF) grants OCE89-22620 and OCE9217334 to K. L. Smith Jr., Scripps Institution of Oceanography. A. G. Carey Jr.'s research (specimens from Oregon) was supported by Atomic Energy Commission contracts AT (45-1)-1750 and AT (45-1)-2227, NSF grants GA-42655, GA-43202, GB-531, and GB-4629, and National Oceanic and Atmospheric Administration Sea grant 2-5187. Manuscript accepted 10 July 2001.

${ }^{2}$ Department of Ecology and Evolutionary Biology, and Natural History Museum and Biodiversity Research Center, 1200 Sunnyside Avenue, University of Kansas, Lawrence, Kansas 66045 (E-mail address of first author: fautin@ku.edu).

${ }^{3}$ Current address: University of Washington, School of Aquatic and Fishery Sciences, Seattle, Washington 98105 .

Pacific Science (2002), vol. 56, no. 2:113-124

(C) 2002 by University of Hawai'i Press.

All rights reserved "stony" corals (order Scleractinia) than with anemones sensu stricto (order Actiniaria) (e.g., den Hartog 1980, Fautin et al. 1999, Romano and Cairns 2000). The corallimorpharian species Corynactis californica Carlgren, 1936, is well documented in shallow Northeast Pacific waters from British Columbia to Baja California (e.g., Harbo 1999). Corallimorpharians from deep waters of the Northeast Pacific are common in museum collections but have not been identified beyond genus Corallimorphus (e.g., Fautin et al. 1987); we have found that they belong to two species, both new to science.

We identify as Corallimorpbus denbartogi, n. sp. (Figure 1) 508 specimens taken at 2550 $4300 \mathrm{~m}$ from Oregon to Baja California. Superficially they can be divided into two groups based on column height and form, but in all taxonomically important respects, members of the two groups are indistinguishable, and individuals of both types were collected together. They have relatively short tentacles and none of the specimens we examined exceeds $70 \mathrm{~mm}$ in oral or pedal disk diameter. Thirty-four specimens we identify as Corallimorphus pilatus, n. sp. (Figure 2) were taken at 198-900 $\mathrm{m}$ from British Columbia to the vicinity of $\mathrm{La}$ Jolla, California. Consider- 


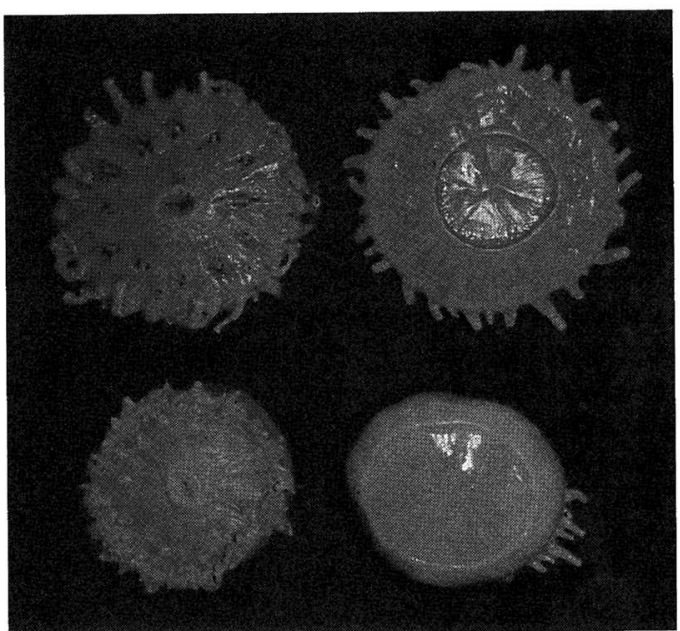

Figure 1. Corallinorphus denhartogi, n. sp. Top: Specimens in which the pedal disk diameter is less than half that of the oral disk (specimen at left is paratype mLML C 0193; the greatest diameter of its oral disk is $42 \mathrm{~mm}$ ). Bottom: Specimens in which the pedal disk diameter is more than half that of the oral disk.

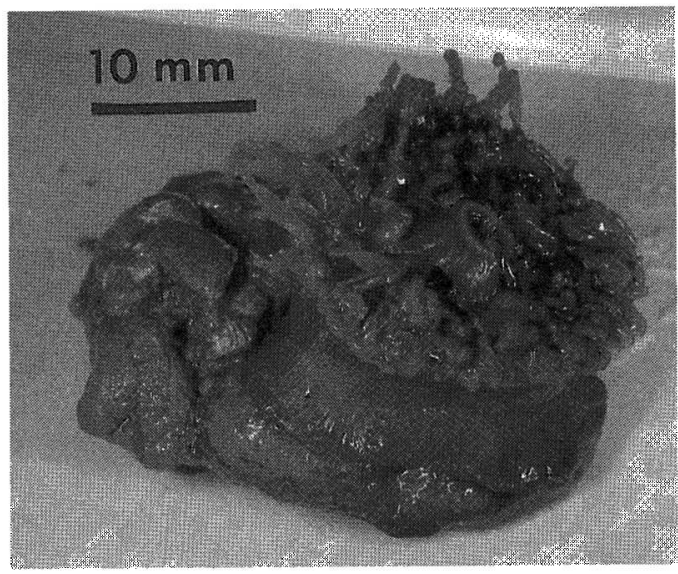

Figure 2. Holotype of Corallimorpbus pilatus, n. $\mathrm{sp}$. ( $\mathrm{RBCM}$ 001-0044-001).

ably smaller than $C$. denbartogi, they have relatively long and densely arrayed tentacles. Specimens of $C$. pilatus have been displayed alive at the Monterey Bay Aquarium.

Seven species have been described in the genus Corallimorpbus (Fautin 2001). 'They are C. profundus Mosley, 1877 (type species);
C. rigidus Mosley, 1877; C. obtectus Hertwig, 1888; C. ingens Gravier, 1918; C. stephensoni Carlgren, 1928; C. antarcticus Carlgren \& Stephenson, 1929; and C. atlanticus Carlgren, 1934. In his catalog of sea anemones of the world, Carlgren (1949) recognized six species; he questionably synonymized $C$. stephensoni with $C$. ingens, and also synonymized Isocorallium bertwigi Carlgren, 1900, with $C$. rigidus. One of us (Fautin 1984) subsequently reduced that number to four by synonymizing $C$. antarcticus with $C$. profundus, and $C$. obtectus with $C$. rigidus. Specimens of the genus Corallimorphus may be obtained in poor condition, and developmental abnormalities are common (Fautin 1984). Both these factors have contributed to taxonomic confusion and the creation of more names than is warranted.

The species of Corallimorpbus can be divided into two groups based on tentacle number: a member of the rigidus group has about twice as many marginal as discal tentacles, whereas a member of the profundus group has about four times as many marginal as discal tentacles. Corallimorpbus denbartogi belongs to the rigidus group, and $C$. pilatus belongs to the profundus group. One of us (Fautin 1984) and den Hartog et al. (1993) summarized opinions about the significance of tentacle number in Corallimorpbus.

The two previously known species that had been recorded from the Pacific are $C$. profundus and $C$. rigidus. The known distribution of $C$. profundus is south of $33^{\circ} 42^{\prime} \mathrm{S}$ in the South Pacific, and around Antarctica except between $38^{\circ} \mathrm{W}$ and $93^{\circ} \mathrm{E}$, at depths from 42 to 3702 m (summarized by Fautin 1984). Corallimorphus rigidus has a more northerly distribution, from $31^{\circ} \mathrm{N}$ off Japan, south through Indonesia and the South Pacific to $60^{\circ} \mathrm{S}$, from nearly $7^{\circ} \mathrm{N}$ in the Indian Ocean to the Great Australian Bight, and off both sides of southern South America, at depths from 245 to $4429 \mathrm{~m}$ (summarized by Fautin 1984).

\section{MATERIALS AND METHODS}

Some of the approximately 500 specimens of Corallimorpbus denbartogi we studied were trawled by K. L. Smith Jr. from $220 \mathrm{~km}$ off 
the coast of California, at $34^{\circ} 50^{\prime} \mathrm{N}, 123^{\circ} 00^{\prime}$ $\mathrm{W}$, and $4100 \mathrm{~m}$ (fig. 1 in Lauerman et al. 1996); they are now part of the collection of the University of Kansas Natural History Museum (кunнm), Lawrence, Kansas. Some were trawled by A. G. Carey Jr. from stations approximately $1200 \mathrm{~km}$ off the coast of Oregon, centered around $45^{\circ} \mathrm{N}, 135^{\circ} \mathrm{W}$, at $3700-3900 \mathrm{~m}$; they are now part of the collection of the Santa Barbara Museum of Natural History (SBMNH), Santa Barbara, California. These animals came from some of the same collections as anemones studied by White et al. (1999). Specimens from southern California and Baja California are part of the collection of the Scripps Institution of Oceanography (sro), La Jolla, California. Specimens of Corallimorpbus pilatus collected by employees of the Monterey Bay Aquarium and the Monterey Bay Aquarium Research Institute in Monterey Bay and Monterey Canyon, California, are deposited in the xunHm. We also examined specimens from waters of British Columbia that are in the collection of the Royal British Columbia Museum (RвCM), Victoria, British Columbia, Canada; from off central California that are in the collection of the Moss Landing Marine Laboratory (MLML); and from off southern California that are in the sio collection.

Immediately after collection, some specimens were fixed in $10 \%$ buffered formalin and were later transferred to $70 \% \mathrm{EtOH}$; others were preserved immediately in $70 \%$ EtOH.

For histological study, paraffin sections 8 $\mu \mathrm{m}$ thick were stained with hematoxylin and eosin (Humason 1979). Cnidae from mesenterial filaments, actinopharynx, tentacle base, acrosphere, and column were observed with differential interference contrast optics in squash preparations; measurements are of undischarged capsules. Not all tissues were studied in all animals.

In addition to institutions mentioned above, the California Academy of Sciences (Cas), San Francisco, California; the Rijksmuseum van Natuurlijke Historie (RMNH), Leiden, the Netherlands; and the U.S. National Museum of Natural History (USNM), Washington, D.C., hold type specimens.
Corallimorphus denbartogi Fautin, White \& Pearson, n. sp.

Figures 1, 3, 4, 5, 6

BODY FORM AND SIZE: Discoidal. Oral disk 5-70 $\mathrm{mm}$ diameter; pedal disk circular, 5-65 mm diameter; height 3-28 $\mathrm{mm}$. Superficially divisible into two groups: those in which pedal disk diameter less than half that of oral disk (Figure 1, top) and those in which pedal disk diameter more than half that of oral disk (Figure 1, bottom). Animals of the two types occur together and do not differ otherwise.

Ectoderm commonly absent (Figure 3); if present, typically trapped in longitudinal furrows of column or radial furrows of oral disk and around base of tentacles. Yellowish color; hyaline in appearance, presumably because of exposed mesoglea; remnants of ectoderm yellow, violet, or brown (Figure 1, top left).

ORAL DISK AND TENTACLES: Oral disk circular, flat or slightly domed, commonly raised around mouth that is slitlike to ovoid;

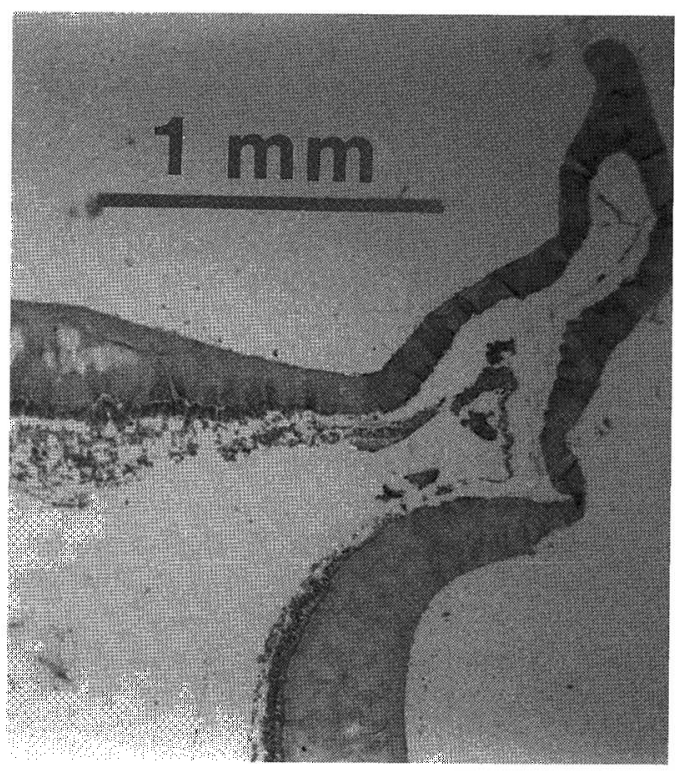

Figure 3. Longitudinal section at margin of Corallimorpbus denbartogi, n. sp. (holotype: кuNнм 001391). Note absence of sphincter muscle, taper of acellular mesoglea, and absence of ectoderm. 
TABLE 1

Dimensions (mm) of Marginal Tentacles in Three Specimens of Corallimorphus denhartogi

\begin{tabular}{|c|c|c|c|c|c|c|c|c|}
\hline \multirow[b]{2}{*}{$\begin{array}{l}\text { Oral } \\
\text { Disk } \\
\text { Diameter }\end{array}$} & \multicolumn{4}{|c|}{ Primary Marginal Tentacle } & \multicolumn{4}{|c|}{ Exocoelic Tentacle } \\
\hline & Length & $\begin{array}{c}\text { Basal } \\
\text { Diameter }\end{array}$ & $\begin{array}{c}\text { Diameter } \\
\text { below } \\
\text { Acrosphere }\end{array}$ & $\begin{array}{l}\text { Acrosphere } \\
\text { Diameter }\end{array}$ & Length & $\begin{array}{c}\text { Basal } \\
\text { Diameter }\end{array}$ & $\begin{array}{l}\text { Diameter } \\
\text { below } \\
\text { Acrosphere }\end{array}$ & $\begin{array}{c}\text { Acrosphere } \\
\text { Diameter }\end{array}$ \\
\hline 50 & 7 & 5 & 1.5 & 2 & 3 & 2 & Nearly 1 & 1 \\
\hline 33 & 7 & 2 & Nearly 1 & 1 & 2 & 1 & Nearly 0.5 & 0.5 \\
\hline 15 & 4.5 & 1 & Nearly 1 & 1 & 1 & $<0.5$ & $<0.5$ & $<0.5$ \\
\hline
\end{tabular}

mouth as much as a third oral disk diameter; distalmost portion of yellow, rugose actinopharynx commonly visible, shallow furrows may radiate from mouth. Tentacles sparse, so disk easily visible (Figure 1). Mesenterial insertions visible as dark or light lines through disk especially around mouth. Marginal tentacles alternately large and small, radiating from or oriented perpendicular to oral disk plane.

Tentacles tapered, capitate; rare ones bifurcate; acrospheres break off easily. Marginal tentacles larger than discal; see Table 1 for dimensions of marginal tentacles. Some tentacles mere nubbins (i.e., less than $1 \mathrm{~mm}$ long).

One marginal tentacle communicates with each exocoel and endocoel, one discal tentacle communicates with each endocoel, so predominant ratio of marginal:discal tentacles 2:1 (Figure 4); rarely more than two tentacles communicate with an endocoel. Number of marginal tentacles 35-51, modal number 48 in 110 specimens in which they were counted. Irregularities common: for example, two exocoelic tentacles between a primary and tertiary tentacle, two sets of tertiary tentacles (alternating with exocoelic tentacles) between a primary and a secondary one. Modal number of discal tentacles 24, range $0-33$ in the 110 specimens. Entire tentacle can break off, which may account for some low numbers, but most variability probably real. Discal tentacles in cycles: the 6 largest, which communicate with primary endocoels, nearest mouth; the 6 communicating with secondary endocoels slightly smaller and slightly nearer margin; the 12 communicating with tertiary endocoels nearest margin and smallest. This arrangement diagrammed in fig. $50 E$ of den Hartog et al. (1993).

column: Smooth; mesenterial insertions visible through it as dark lines. Shallow longitudinal furrows that may retain ectoderm few, irregular; do not correspond in position to mesenterial insertions.

PEDAL DISK: Flat to slightly concave; limbus extends below it in most individuals, turned under in some. Mesenterial insertions visible through it as dark or light lines.

MESENTERIES AND INTERNAL ANATOMY: Internal structures commonly poorly preserved. Typically 24 pairs of mesenteries, 12 pairs (primaries and secondaries) complete, directive mesenteries not distinguishable. Retractor muscles indistinct (Figure 5); parietobasilar muscles absent. All mesenteries fertile (Figure 5): sexes separate, eggs yellow to 1 $\mathrm{mm}$ diameter in preservation.

Actinopharynx deeply sulcate, without siphonoglyphs; ectoderm of actinopharynx commonly sloughed off. 3).

Marginal sphincter muscle absent (Figure

Mesoglea acellular, transparent, can be thick; with fibers between ectoderm and endoderm, and scattered holes in fixed material (Figure 3). Typically, mesoglea of oral disk tapers toward mouth and margin (Figure 3) so thickest halfway across or near margin: to $2 \mathrm{~mm}$ thick in individuals 33 and $45 \mathrm{~mm}$ oral disk diameter, $3 \mathrm{~mm}$ thick in one $48 \mathrm{~mm}$ diameter, but $0.5 \mathrm{~mm}$ thick in another $33 \mathrm{~mm}$ diameter. Mesoglea of column may taper at 


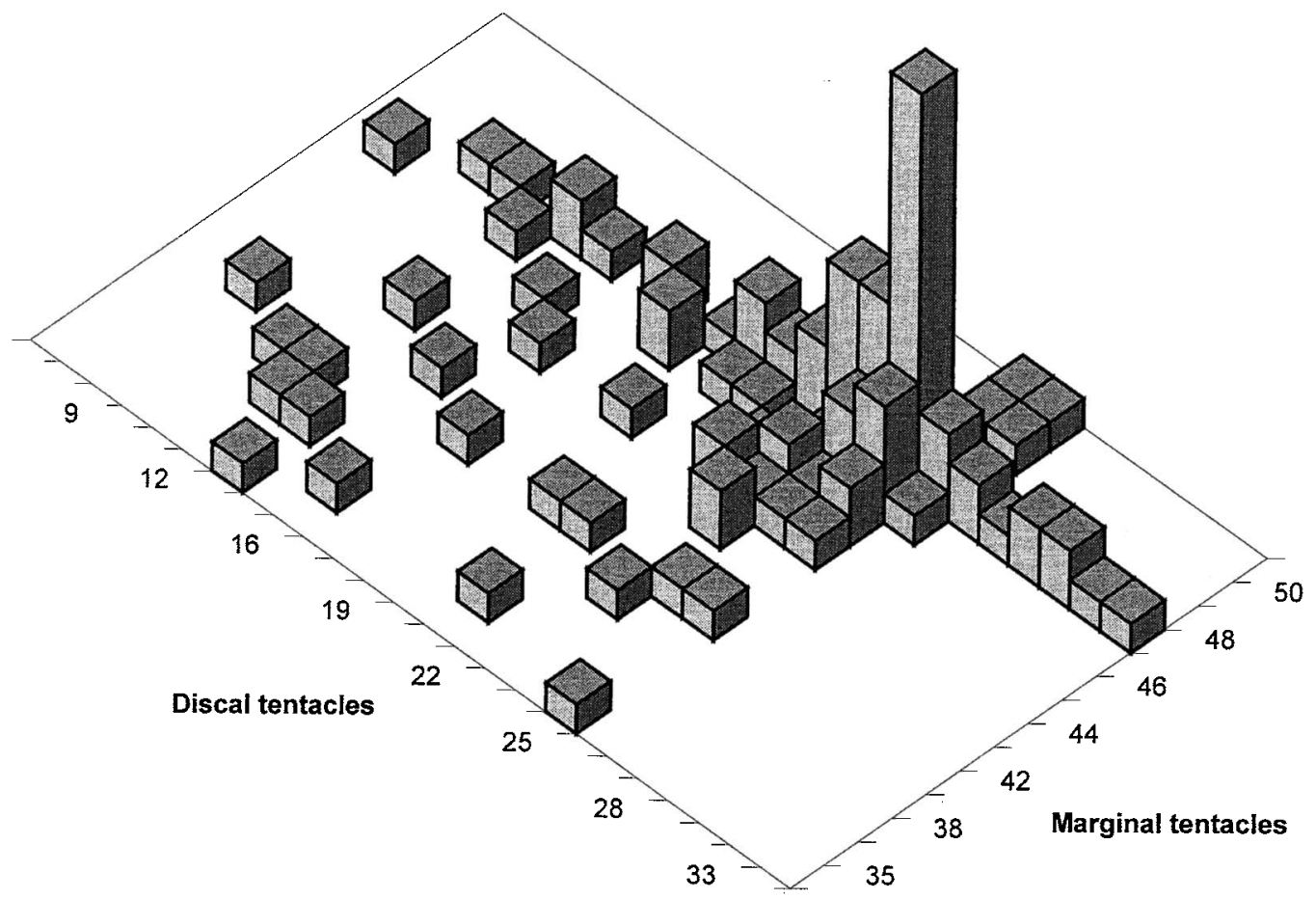

FIGURE 4. Number of marginal and discal tentacles in 110 specimens of Corallimorphus denhartogi, n. sp. The longest bar represents 14 individuals with 48 marginal and 24 discal tentacles; each of the two bars to its left represents six individuals; and each of the lowest bars (of which there are 46) represents a single individual.

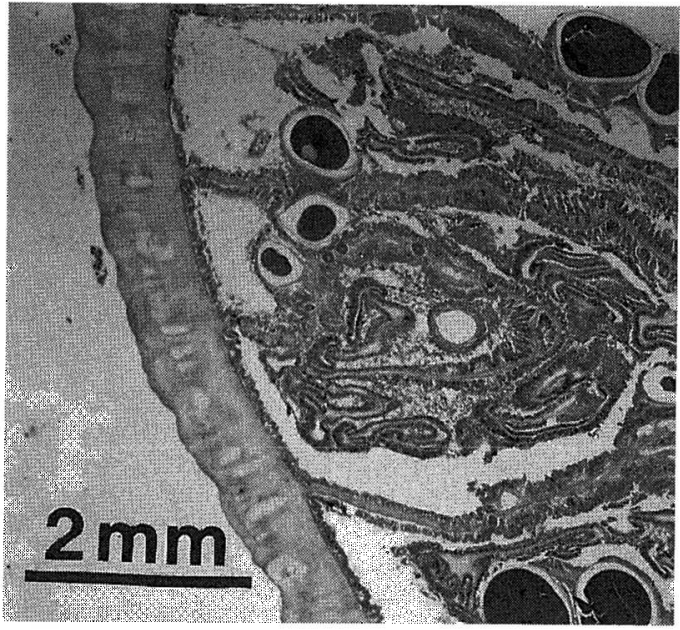

Figure 5. Cross section through midcolumn of Corallimorphus denbartogi, n. sp. (holotype: кuNHм 001391). Note thickness of acellular mesoglea, holes in mesoglea, absence of ectoderm, and shallowness and irregularity of longitudinal furrows. margin and limbus with mesoglea thickest just proximal to margin (nearly $2 \mathrm{~mm}$ in animal with oral disk diameter $30 \mathrm{~mm}$ ), or at limbus.

CNIDOME: Spirocysts, basitrichs, microbasic $p$-mastigophores, microbasic $b$-mastigophores, and holotrichs.

Size and distribution of cnidae given in Table 2, illustrated in Figure 6. Erosion of tentacle ectoderm in most individuals may be responsible for the small numbers of cnidae of some types found in some individuals.

ETYMOLOGY: This species is named in honor of J. C. den Hartog (1942-2000), a naturalist who was a taxonomic authority on corallimorpharians, and who was a curator at the Rijksmuseum van Natuurlijke Historie, Leiden.

type specimens: See Table 3. Histological slides were made from most type specimens. 
TABLE 2

Cnidae of Corallimorphus denbartogi (Letters in Parentheses Refer to Illustrations in Figure 6)

\begin{tabular}{|c|c|c|}
\hline Character & \multicolumn{2}{|c|}{ Measurements } \\
\hline \multicolumn{3}{|l|}{ Marginal tentacle acrosphere } \\
\hline Spirocyst $(a)$ & $33.1-74.6 \times 3.1-7.4$ & $n=17, N=4 / 8$ \\
\hline Holotrich $(b)$ & $29.8-63.2 \times 4.6-12.8$ & $n=54, N=7 / 8$ \\
\hline Hoplotelic microbasic $b$-mastigophore $(c)$ & $11.1-34.1 \times 4.2-8.2$ & $n=103, N=8 / 8$ \\
\hline${ }^{*}$ Holotrich & $12.0-26.7 \times 7.4-12.8$ & $n=10, N=1 / 8$ \\
\hline${ }^{*}$ Holotrich & $164.0-221.4 \times 16.4-27.5$ & $n=6, N=1 / 8$ \\
\hline${ }^{*}$ Microbasic $p$-mastigophore & $105.2-191.5 \times 6.7-10.7$ & $n=13, N=2 / 8$ \\
\hline \multicolumn{3}{|l|}{ Base of discal tentacle } \\
\hline Spirocyst $(a)$ & (12.3) $18.4-47.0 \times 2.3-6.2$ & $n=40, N=6 / 8$ \\
\hline Microbasic $p$-mastigophore $(d)$ & $16.6-32.0 \times 5.2-9.0$ & $n=41, N=6 / 8$ \\
\hline Hoplotelic microbasic $b$-mastigophore $(c)$ & $14.1-26.2 \times 4.5-7.9$ & $n=68, N=7 / 8$ \\
\hline \multicolumn{3}{|l|}{ Actinopharynx } \\
\hline Holotrich $(e)$ & $66.7-115.9 \times 10.4-29.7$ & $n=87, N=10 / 10$ \\
\hline Hoplotelic microbasic $b$-mastigophore $(f)$ & $42.2-90.5 \times 9.7-18.6$ & $n=113, N=10 / 10$ \\
\hline \multicolumn{3}{|l|}{ Mesenterial filaments } \\
\hline Holotrich $(b)$ & $22.6-61.1 \times(4.4) 6.3-13.8$ & $n=27, N=6 / 11$ \\
\hline Holotrich $(e)$ & $61.2-123.4 \times 11.6-26.2$ & $n=100, N=10 / 11$ \\
\hline Hoplotelic microbasic $p$-mastigophore $(g)$ & $43.1-102.6 \times 5.8-12.2$ & $n=79, N=8 / 11$ \\
\hline Hoplotelic microbasic $b$-mastigophore $(c)$ & $13.3-25.0 \times 3.5-8.1$ & $n=114, N=10 / 11$ \\
\hline $\begin{array}{l}\text { Hoplotelic microbasic } b \text {-mastigophore }(f) \text { (inferred } \\
\text { to be a contaminant from the actinopharynx) }\end{array}$ & $37.8-75.6 \times 10.8-15.3$ & $n=40, N=5 / 11$ \\
\hline \multicolumn{3}{|l|}{ Column } \\
\hline Hoplotelic microbasic $p$-mastigophore $(d)$ & $16.7-36.0 \times 5.9-9.6$ & $n=36, N=4 / 4$ \\
\hline Hoplotelic microbasic $b$-mastigophore $(c)$ & $13.7-23.7 \times 4.5-7.5$ & $n=22, N=3 / 4$ \\
\hline
\end{tabular}

Note: Measurements are ranges first of length, followed by width, in $\mu \mathrm{m}$. Numbers in parentheses are of single capsules that fell outside the typical range; $n$ is the number of capsules measured, and $N$ is the number of specimens in which that type of cnida occurred relative to the number in which the tissue was examined. Asterisks indicate cridae that were found in only one or two individuals in small numbers. They are not illustrated because they could not be relocated for photography, but we include them because they were found in ectoderm, which is patchy in these animals, and they were sufficiently abundant that they are unlikely to be contaminants.

Corallimorphus pilatus Fautin, White \& Pearson, n. sp.

Figures 2, 7, 8, 9

BODY FORM AND SIZE: Cylindrical: oral and pedal disks of similar size or one slightly larger than other. Oral disk in preserved specimens studied circular to ovoid, $2-35 \mathrm{~mm}$ diameter; pedal disk circular, $2.5-35 \mathrm{~mm}$ diameter; height $3-20 \mathrm{~mm}$. In living specimens, diameter to $60 \mathrm{~mm}$ and height to $40 \mathrm{~mm}$. Yellowish ectoderm present only in patches on column of preserved specimens; brownish ectoderm on oral disk around tentacles and at base of tentacles of some specimens; tentacle acrospheres white. Otherwise animal yellowish or pinkish; hyaline in appearance, presumably because of exposed mesoglea. Column of some living individuals translucent to nearly transparent, others uniform purplish; tentacles opaque white.

ORAL DISK AND TENTACLES: Oral disk commonly raised around mouth. Mouth typically a slit a quarter to a third oral disk diameter; tan in live or recently preserved animals. Longitudinal corrugations of actinopharynx visible at mouth opening. Due to length and number, tentacles obscure most of oral disk (Figure 2).

Tentacles tapered, capitate, longitudinally furrowed; rare ones bifurcate. Those arising from disk slightly longer than disk radius: 15 $\mathrm{mm}$ in animal of $25 \mathrm{~mm}$ diameter, $17 \mathrm{~mm}$ in animal of $35 \mathrm{~mm}$ diameter. Tentacle $15 \mathrm{~mm}$ long had basal diameter $2 \mathrm{~mm}$ and acrosphere $1 \mathrm{~mm}$ diameter. Marginal tentacles to about 

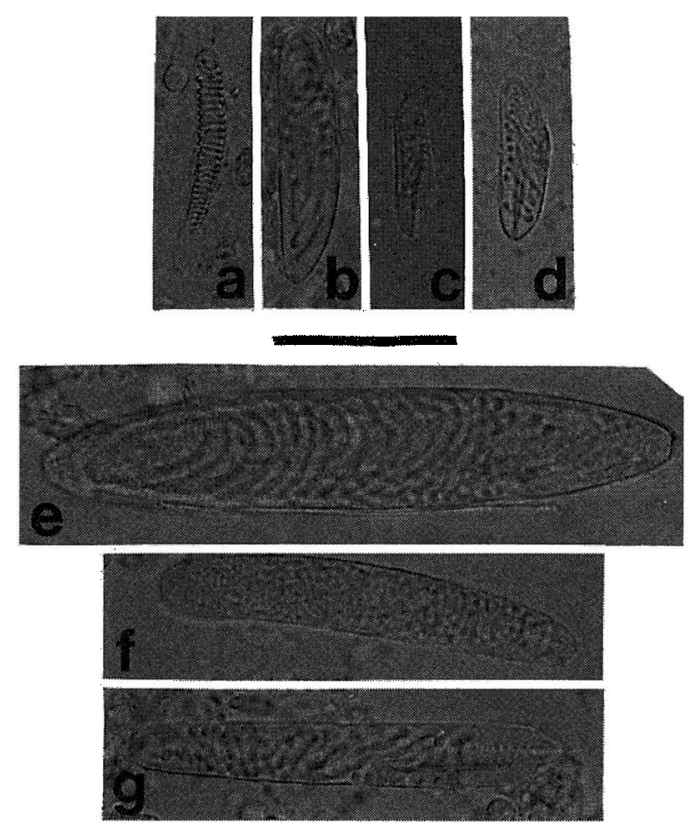

Figure 6. Nematocysts of Corallimorphus denhartogi, $\mathrm{n}$. sp. Scale bar represents $30 \mu \mathrm{m}$. See Table 2 for explanation. one-third length of discal ones and $1 \mathrm{~mm}$ basal diameter, but may be mere nubbins. In a live individual $60 \mathrm{~mm}$ diameter, largest tentacle $15 \mathrm{~mm}$ long; smallest tentacle $5 \mathrm{~mm}$ long, diameter slightly more than $1 \mathrm{~mm}$ at base and acrosphere.

Tentacles difficult to count: discal tentacles concentrated near margin, which may be flared. Ideal ratio 4:1 marginal:discal tentacles (96 marginal $=6$ primary, 6 secondary, 12 tertiary, and 24 fourth-order endocoelic ones, plus 48 exocoelic ones; 24 discal $=$ one communicating with each primary, secondary, and tertiary endocoel). Commonly ratio nearer 2.6-3:1, presumably due to delayed growth of some fourth-order tentacles and broken or rudimentary ones.

column: Distalmost end flared in some individuals. Shallow longitudinal furrows numerous, regularly spaced, giving cross sections of scalloped appearance (Figure 7); furrows retain ectoderm, do not correspond in position to mesenterial insertions, which may be visible through smooth column as light lines.

TABLE 3

Type and Voucher Specimens of Corallimorpbus denbartogi

\begin{tabular}{|c|c|c|c|c|c|}
\hline Institution & Status & Catalog No. & Locality & Depth (m) & $\begin{array}{l}\text { No. of } \\
\text { Specimens }\end{array}$ \\
\hline \multirow[t]{2}{*}{ KUNHM } & Holotype & 001391 & $34^{\circ} 43^{\prime} \mathrm{N}, 123^{\circ} 11^{\prime} \mathrm{W}$ & 4,100 & 1 \\
\hline & Paratypes & 001528 & $36^{\circ} 15.94^{\prime} \mathrm{N}, 122^{\circ} 36.66^{\prime} \mathrm{W}$ & $2,820-2,960$ & 4 \\
\hline \multirow[t]{2}{*}{ CAS } & Paratype & 146043 & $34^{\circ} 42^{\prime} \mathrm{N}, 123^{\circ} 09^{\prime} \mathrm{W}$ & 4,100 & 1 \\
\hline & Paratype & 154362 & $37^{\circ} 04.44^{\prime} \mathrm{N}, 123^{\circ} 24.40^{\prime} \mathrm{W}$ & $3,175-3,180$ & 1 \\
\hline MLML & Paratype & C 0193 & $37^{\circ} 38.62^{\prime} \mathrm{N}, 123^{\circ} 28.03^{\prime} \mathrm{W}$ & $2,945-? 3,075$ & 1 \\
\hline $\mathrm{RBCM}$ & Paratype & $001-0046-001$ & $34^{\circ} 40^{\prime} \mathrm{N}, 123^{\circ} 11^{\prime} \mathrm{W}$ & 4,100 & 1 \\
\hline RMNH & Paratype & Coel. 24967 & $34^{\circ} 47^{\prime} \mathrm{N}, 123^{\circ} 07^{\prime} \mathrm{W}$ & 4,134 & 1 \\
\hline \multirow[t]{2}{*}{ SBMNH } & Paratypes & 144410 & $44^{\circ} 43^{\prime} 18^{\prime \prime} \mathrm{N}, 127^{\circ} 22^{\prime} 48^{\prime \prime} \mathrm{W}$ & 3,021 & 2 \\
\hline & Paratype & 144411 & $\begin{array}{l}\text { Mendocino County, California; } \\
\mathrm{S} \text { of Mendocino Ridge, } W \\
\text { of Delgado Fan }\end{array}$ & 4,250 & 1 \\
\hline \multirow[t]{2}{*}{ sio } & Paratype & Co 1388 & $\begin{array}{l}31^{\circ} 24^{\prime} \mathrm{N}, 120^{\circ} 14.5^{\prime} \mathrm{W}- \\
31^{\circ} 28.2^{\prime} \mathrm{N}, 120^{\circ} 10.3^{\prime} \mathrm{W}\end{array}$ & 3,880 & 1 \\
\hline & Vouchers & Co 2001 & $\begin{array}{l}37^{\circ} 22^{\prime} \mathrm{N}, 123^{\circ} 54^{\prime} \mathrm{W}- \\
37^{\circ} 16^{\prime} \mathrm{N}, 123^{\circ} 53^{\prime} \mathrm{W}\end{array}$ & $3,592-3,798$ & 3 \\
\hline \multirow[t]{2}{*}{ USNM } & Paratype & 100903 & $34^{\circ} 44^{\prime} \mathrm{N}, 123^{\circ} 07^{\prime} \mathrm{W}$ & 4,100 & 1 \\
\hline & Paratypes & 1000047 & $37^{\circ} 38.53^{\prime} \mathrm{N}, 123^{\circ} 29.23^{\prime} \mathrm{W}$ & $2,975-3,010$ & 2 \\
\hline
\end{tabular}




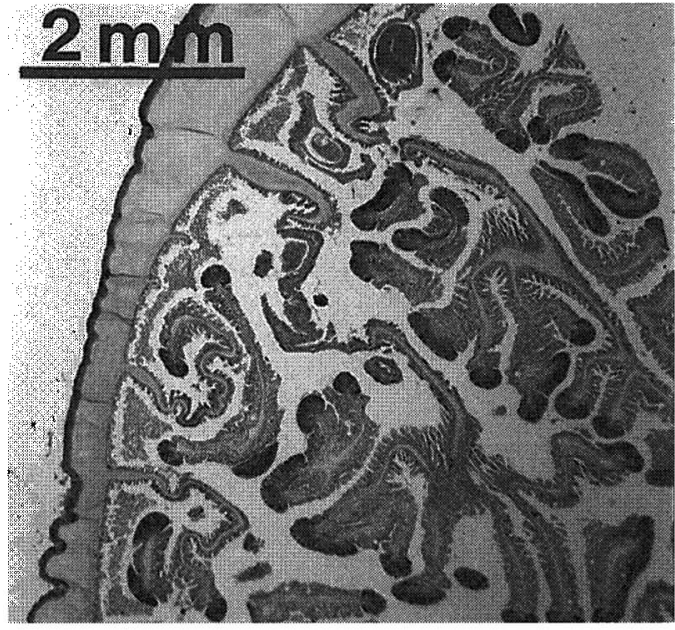

Figure 7. Cross section through midcolumn of Corallimorphus pilatus, n. sp. (holotype: Rв в Note thickness of mesoglea, and ectoderm in shallow, regularly spaced longitudinal furrows.

PEDAL DISK: Flat or concave; most specimens studied adherent to stones or shells. Mesenterial insertions not visible through the disk.

MESENTERIES AND INTERNAL ANATOMY: Internal structures commonly poorly preserved. Typically 24 pairs of mesenteries, 12 pairs (primaries and secondaries) complete, directive mesenteries not distinguishable. Retractor muscles indistinct (Figure 7); parietobasilar muscles absent. All mesenteries fertile (Figure 7): sexes separate, eggs yellow to 1 $\mathrm{mm}$ diameter in preservation.

Actinopharynx rugose, lacking siphonoglyphs; partly or completely brown in specimens examined. 8).

Marginal sphincter muscle absent (Figure

Mesoglea transparent, thick, with sparsely scattered small nuclei (Figure 8). Typically tapers toward mouth and margin (Figure 8) so thickest halfway across oral disk. Mesoglea of column tapers at margin and limbus with mesoglea thickest halfway between.

CNIDOME: Spirocysts, basitrichs, microbasic $p$-mastigophores, microbasic $b$-mastigophores, and holotrichs.

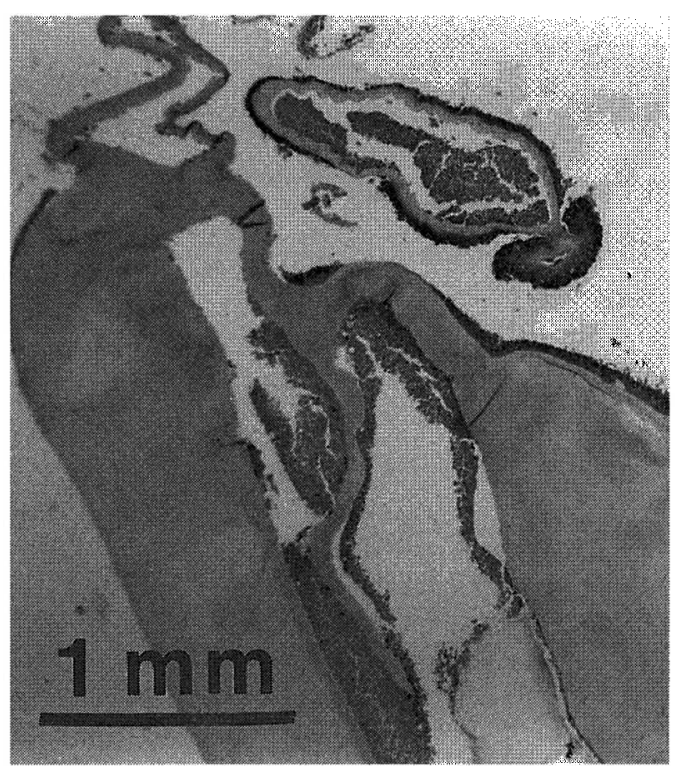

Figure 8. Longitudinal section at margin of Corallimorphus pilatus, n. sp. (holotype: ввсм 001-0044-001). Note absence of sphincter muscle, taper of mesoglea, and nuclei in mesoglea (especially at the margin).

Size and distribution of cnidae given in Table 4, illustrated in Figure 9.

eTYMology: The name "pilatus," which is in the nominative singular and is masculine, means thick or dense in reference to hair. The name refers to the density of tentacles relative to the coverage in $C$. denbartogi.

NATURAL HISTORY: Judging by the presence of small individuals surrounding a large one in two samples, animals of this species may reproduce asexually by means of pedal laceration. Eggs were seen free in the gastrovascular cavity; they may move into tentacles. We found unfired hydrozoan nematocysts in squash preparations of mesenterial filaments from two specimens; we therefore infer that individuals of $C$. pilatus eat hydrozoans. One of the paratypes from lot sio Co 2009 was attached to the shell of a bivalve and the other was attached to the shell of a brachiopod.

TYPE SPECIMENS: See Table 5. Histological slides were made from most type specimens. 


\section{TABLE 4}

Cnidae of Corallimorpbus pilatus (Letters in Parentheses Refer to Illustrations in Figure 9)

\begin{tabular}{lcc}
\hline \hline Character & \multicolumn{2}{c}{ Measurements } \\
\hline Marginal tentacle acrosphere & & \\
Spirocyst $(a)$ & $25.5-68.7 \times 2.0-5.3$ & $n=17, N=3 / 4$ \\
Holotrich $(b)$ & $19.9-43.1 \times 5.8-12.6$ & $n=11, N=3 / 4$ \\
Holotrich $(c)$ & $91.1-161.4 \times 7.9-16.1$ & $n=14, N=2 / 4$ \\
$\quad$ Hoplotelic microbasic p-mastigophore $(d)$ & $80.3-155.3 \times 4.9-9.9$ & $n=13, N=2 / 4$ \\
$\quad$ Hoplotelic microbasic $b$-mastigophore $(e)$ & $7.7-27.6 \times 2.9-6.7$ & $n=28, N=4 / 4$ \\
$\quad$ Hoplotelic microbasic $b$-mastigophore $(f)$ & & $n=33, N=3 / 4$ \\
Base of discal tentacle & $16.7-31.3 \times 2.7-5.5$ & $n=11, N=3 / 4$ \\
$\quad$ Spirocyst $(a)$ & $9.9-29.1 \times 3.2-7.5$ & $n=36, N=4 / 4$ \\
$\quad$ Hoplotelic microbasic p-mastigophore $(g)$ & $6.3-11.2 \times 2.4-4.6$ & $n=10, N=1 / 4$ \\
$\quad$ Hoplotelic microbasic $b$-mastigophore $(b)$ & $20.9-57.5 \times 5.0-13.9$ & $n=42, N=4 / 4$ \\
Actinopharynx & & \\
$\quad$ Holotrich $(i)$ & $34.8-89.7 \times 8.2-21.4$ & $n=44, N=4 / 4$ \\
Mesenterial filaments & $19.3-66.4 \times 4.3-11.4$ & $n=34, N=4 / 4$ \\
$\quad$ Holotrich $(b)$ & $8.3-25.7 \times 4.0-6.7$ & $n=13, N=3 / 4$ \\
$\quad$ Hoplotelic microbasic $p$-mastigophore $(g)$ & $12.3-28.0 \times 3.2-8.9$ & $n=41, N=4 / 4$ \\
Hoplotelic microbasic $b$-mastigophore $(f)$ & $4.9-21.5 \times 2.0-6.1$ & $n=29, N=4 / 4$ \\
Column & & \\
$\quad$ Hoplotelic microbasic $p$-mastigophore $(g)$ & & \\
Hoplotelic microbasic $b$-mastigophore $(b)$ &
\end{tabular}

Note: Measurements are ranges first of length, followed by width, in $\mu \mathrm{m}$. Numbers in parentheses are of single capsules that fell outside the typical range; $n$ is the number of capsules measured, and $N$ is the number of specimens in which that type of crida occurred relative to the number in which the tissue was examined.
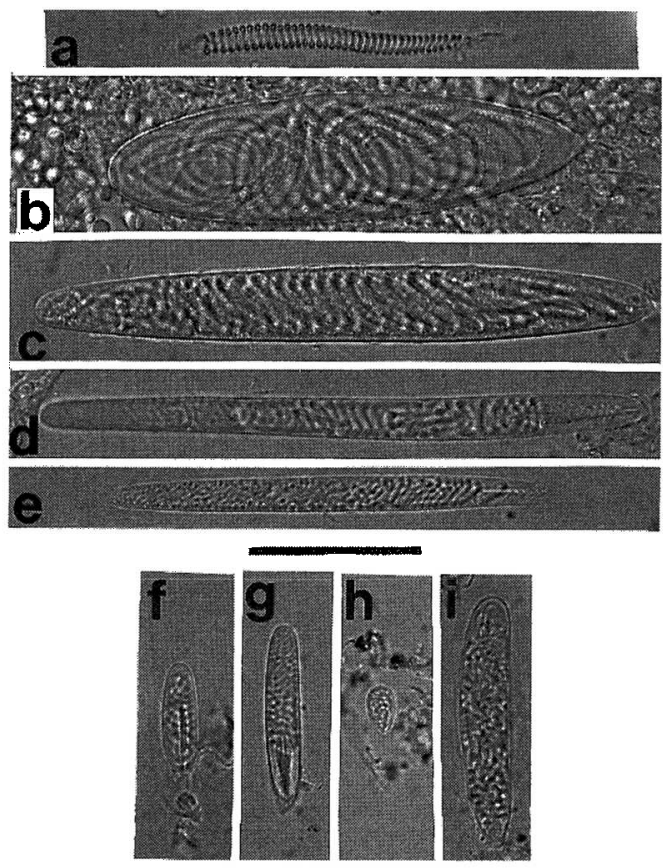

Figure 9. Nematocysts of Corallimorphus pilatus, n. sp. Scale bar represents $30 \mu \mathrm{m}$. See Table 4 for explanation.

\section{DIFFERENTIAL DIAGNOSIS}

The two new species we describe, Corallimorpbus denbartogi and C. pilatus, can be distinguished from one another on several grounds. The former has very short tentacles and a relatively expansive oral disk that is not obscured by the tentacles arising from and around it, whereas the relatively long tentacles of $C$. pilatus may obscure the oral disk. The definitive ratio of marginal:discal tentacles is $2: 1$ in $C$. denhartogi, and $4: 1$ in $C$. pilatus, although this feature can vary, and at the penultimate stage of development, $C$. pilatus has only twice as many marginal as discal tentacles. Compared with that of $C$. denhartogi, the column of $C$. pilatus is relatively longer, is more cylindrical, and has more numerous longitudinal furrows that are more regularly spaced. There are differences in nematocysts: for example, hoplotelic microbasic $b$-mastigophores are present in the actinopharynx of $C$. denhartogi but absent in $C$. pilatus. There are also size differences: for example, the mesenterial filaments of $C$. 


\section{TABLE 5}

Type and Voucher Specimens of Corallimorpbus pilatus

\begin{tabular}{lllccc}
\hline \hline Institution & Status & Catalog No. & \multicolumn{1}{c}{ Locality } & Depth (m) & $\begin{array}{c}\text { No. of } \\
\text { Specimens }\end{array}$ \\
\hline RBCM & Holotype & $001-0044-001$ & $48^{\circ} 53.1^{\prime} \mathrm{N}, 126^{\circ} 54.5^{\prime} \mathrm{W}$ & 900 & 1 \\
& Paratype & $988-258-8$ & $48^{\circ} 25.6^{\prime} \mathrm{N}, 126^{\circ} 08.6^{\prime} \mathrm{W}$ & 315 & 1 \\
& Vouchers & $988-268-34$ & $48^{\circ} 53.1^{\prime} \mathrm{N}, 126^{\circ} 54.5^{\prime} \mathrm{W}$ & 900 & 7 \\
CAS & Paratype & 152514 & $48^{\circ} 53.1^{\prime} \mathrm{N}, 126^{\circ} 54.5^{\prime} \mathrm{W}$ & 900 & 1 \\
sUNHM & Paratype & 001392 & $36^{\circ} 45.32^{\prime} \mathrm{N}, 121^{\circ} 58.26^{\prime} \mathrm{W}$ & 490 & 1 \\
& Paratype & 001393 & $36^{\circ} 45.32^{\prime} \mathrm{N}, 121^{\circ} 58.26^{\prime} \mathrm{W}$ & 490 & 1 \\
\multirow{2}{*}{ SBMNH } & Paratype & 001394 & $48^{\circ} 53.1^{\prime} \mathrm{N}, 126^{\circ} 54.5^{\prime} \mathrm{W}$ & 900 & 1 \\
SIO & Paratypes & 144409 & $45^{\circ} 52^{\prime} 42^{\prime \prime} \mathrm{N}, 124^{\circ} 53^{\prime} 48^{\prime \prime} \mathrm{W}$ & 840 & 2 \\
& Paratypes & Co 2009 & $32^{\circ} 55.5^{\prime} \mathrm{N}, 117^{\circ} 37.4^{\prime} \mathrm{W}-$ & 896 & 2 \\
USNM & Paratype & 100904 & $32^{\circ} 51.0^{\prime} \mathrm{N}, 117^{\circ} 36.0^{\prime} \mathrm{W}$ & & 1 \\
\hline
\end{tabular}

denhartogi have holotrichs of two size classes whereas in $C$. pilatus there is a single class of intermediate size. Typically, scattered in the mesoglea of $C$. denhartogi are large holes and in that of C. pilatus are small nuclei. Individuals of $C$. denhartogi have been collected from deeper water than those of $C$. pilatus and have a wider bathymetric range.

Corallimorphus denhartogi, having a $2: 1$ marginal: discal tentacle ratio, belongs to the rigidus group. A typical specimen of $C$. rigidus is larger than one of $C$. denhartogi and its tentacles are more robust, especially at the margin. The cnidae of $C$. rigidus are incompletely known (Fautin 1984): the holotrichs of the actinopharynx are of similar size in the two species. The other certain member of the group is $C$. ingens. The hoplotelic microbasic $p$-mastigophores of its column, called penicilli D by den Hartog et al. (1993), are of similar size to those of $C$. denhartogi, but its actinopharynx has only holotrichs, called homotrichs by den Hartog et al. (1993), and they are smaller than those of $C$. denhartogi. Holotrichs are also present in the actinopharynx of $C$. denbartogi but are absent in $C$. ingens. Moreover, $C$. ingens is known only from the Atlantic and, compared with $C$. denbartogi, is more cylindrical and has much longer marginal tentacles (den Hartog et al. 1993). Corallimorpbus atlanticus, which may be synonymous with $C$. rigidus (see Fautin 1984), has hoplotelic microbasic $b$-mastigophores of two size categories in its mesenterial filaments, both of which are larger than those of C. denbartogi, and is also known only from the Atlantic (den Hartog et al. 1993).

With a 4:1 marginal: discal tentacle ratio, C. pilatus belongs to the profundus group, the only other member of which is $C$. profundus, which is known from south of $33^{\circ} \mathrm{S}$ (Fautin 1984). The body and tentacle form of C. pilatus and C. profundus are similar; C. profundus is typically larger. The two differ in cnidae: holotrichs of the acrospheres of $C$. profundus are much larger than those of $C$. pilatus, and the actinopharynx of $C$. profundus contains only holotrichs.

The cnidae of $C$. denhartogi differ from those of C. profundus, and the cnidae of C. pilatus differ from those of $C$. rigidus.

\section{DISCUSSION}

The two new species described here are typical of the genus Corallimorphus in morphological respects, such as the absence and poor development of sphincter and retractor muscles, respectively. As is characteristic of the genus, specimens are typically poorly preserved. Nonetheless, they are distinct from the species of the genus currently recognized (Fautin 1984).

There is a clear mode of 24 discal and 48 marginal tentacles in $C$. denbartogi (Figure 1). The number of discal tentacles declines 
sharply above 24 but rises gradually to 24 (Figure 4), from which we infer that 24 represents the definitive number. Not uncommonly, two discal tentacles arise side by side from an endocoel; this observation is further evidence (e.g., Fautin 1984, den Hartog et al. 1993) that supernumerary tentacles may result from developmental abnormalities in corallimorpharians. Fewer than 24 discal tentacles may be due to one or both of two causes: damage can remove tentacles, and, if the ani$\mathrm{mal}$ was collected before it was fully mature, all of its tentacles might not have formed. Two pieces of evidence support ontogeny being part of the explanation for fewer than 24 discal tentacles: the low-amplitude mode around 12 discal tentacles, and the fact that in those individuals, the tentacles communicate exclusively with the primary and secondary endocoels.

The arrangement of tentacles is less clear in $C$. pilatus because we had fewer specimens to examine and because of the more numerous tentacles of smaller animals. Preceding development of the ultimate cycle of mesenteries, an individual may have 48 marginal and 24 discal tentacles, as did one of the specimens we examined. The other specimens, however, had many more marginal and no more discal tentacles, despite being smaller than most of those of $C$. denhartogi we examined, which makes us confident that the difference in tentacle ratio we observed between the two species is not due to ontogeny.

\section{ACKNOWLEDGMENTS}

We thank Gilbert Van Dykhuizen and Randy Kochevar of the Monterey Bay Aquarium for living specimens of Corallimorphus pilatus, and Nancy Jacobsen Stout of the Monterey Bay Aquarium Research Institute for in situ photographs of animals. A. G. Carey Jr. acknowledges M. A. Ashcraft, R. E. Ruff, R. R. Paul, M. A. Kyte, D. R. Hancock, and other technicians and graduate students for their invaluable assistance. We are grateful to Paul $V$. Scott of the sвмNн for making the specimens collected by Carey available to us, and to Jim Nybakken and Jon Geller of MLML, to Phil Lambert and Kelly Sendall of the RBCM, and to Larry Lovell of sio for making specimens in those collections available to us. We thank Cadet Hand and Meg Daly for suggestions that improved this paper.

\section{Literature Cited}

Carlgren, O. 1900. Ostafrikanische Actinien. Mitt. Naturhist. Mus. 17:21-144.

1928. Actiniaria der deutschen Tiefsee-Expedition. Deutsche TiefseeExped. 1898-1899 22 (4): 123-266.

- 1934. Ceriantharia, Zoantharia and Actiniaria. Rep. Sci. Res. "Michael Sars" North Atlantic Deep-sea Exped. 19105 (6): 1-27.

1936. Some west American sea anemones. J. Wash. Acad. Sci. 26 (1): 16-23.

. 1949. A survey of the Ptychodac-

tiaria, Corallimorpharia and Actiniaria. K. Sven. Vetenskapsakad. Handl., Ser. 4, 1 (1): $1-121$.

Carlgren, O., and T. A. Stephenson. 1929. Actiniaria. Sci. Rep. Australasian Ant. Exped. 1911-1914, ser. C (Zool. and Bot.) 9 (2): 1-34.

Fautin, D. G. 1984. More Antarctic and Subantarctic sea anemones (Coelenterata: Corallimorpharia and Actiniaria). Antarct. Res. Ser. 41 (1): 1-42.

- 2001. Hexacorallians of the world (sea anemones, corals, and their allies): Catalogue of taxa, bibliography of literature in which they were described, inventory of type specimens, distribution maps, and images. http://www.kgs.ukans.edu/ Hexacoral/

Fautin, D. G., S. L. Romano, and W. A. Oliver Jr. 1999. Subclass Zoantharia (= Hexacorallia): Sea anemones and corals. Tree of Life. http://phylogeny.arizona. edu/tree/eukaryotes/animals/cnidaria/ anthozoa/zoantharia/zoantharia.html

Fautin, D. G., A. E. Siebert, and E. N. Kozloff. 1987. Class Anthozoa. Pages 68-78 in E. N. Kozloff, ed. Marine invertebrates of the Pacific Northwest. University of Washington Press, Seattle.

Gravier, Ch. 1918. Note préliminaire sur les Hexactiniaires recueillis au cours des croisières de la Princesse-Alice et de 
l'Hirondelle de 1888 à 1913 inclusivement. Bull. Inst. Océanogr. (Monaco) 346:1-24. Harbo, R. M. 1999. Whelks to whales: Coastal marine life of the Pacific Northwest. Harbour Publishing, Madeira Park, British Columbia.

den Hartog, J. C. 1980. Caribbean shallow water Corallimorpharia. Zool. Verh. (Leiden) 176:1-83.

den Hartog, J. C., O. Ocaña, and A. Brito. 1993. Corallimorpharia collected during the CANCAP expeditions (1976-1986) in the south-eastern part of the North Atlantic. Zool. Verh. (Leiden) 282:1-76.

Hertwig, R. 1888. Report on the Actiniaria dredged by H. M. S. Challenger during the years 1873-1876, Supplement. Sci. Res. Voy. H. M. S. Challenger, Zool. 26 (3): $1-56$.

Humason, G. L. 1979. Animal tissue techniques. 4th ed. Freeman and Co., San Francisco.
Lauerman, L. M. L., R. S. Kaufmann, and K. L. Smith Jr. 1996. Distribution and abundance of epibenthic megafauna at a long time-series station in the abyssal northeast Pacific. Deep-Sea Res. I 43 (7): 10751103.

Mosley, H. N. 1877. On new forms of Actiniaria dredged in the deep sea; with a description of certain pelagic surfaceswimming species. Trans. Linn. Soc., ser. 2, Zool. 1:295-305.

Romano, S. L., and S. D. Cairns. 2000. Molecular phylogenetic hypotheses for the evolution of scleractinian corals. Bull. Mar. Sci. 67 (3): 1043-1068.

White, T. R., A. K. Wakefield Pagels, and D. G. Fautin. 1999. Abyssal sea anemones (Cnidaria: Actiniaria) of the Northeast Pacific symbiotic with molluscs: Anthosactis nomados, a new species, and Monactis vestita (Gravier, 1918). Proc. Biol. Soc. Wash. 112 (4): 637-651. 